Microeconomics

\author{
Nadiya DUBROVINA, \\ Andrzej SIWIEC, \\ Vira DUBROVINA, \\ Oksana TULAI
}

\title{
ANALYSIS OF THE STRATEGIC POSITIONS OF CENTER OF PEDIATRICS: THE PROBLEM OF IMPROVEMENT OF HUMAN RESOURCES MANAGEMENT
}

\begin{abstract}
In the article the problem of analysis of the strategic positions is considered on the example of the Center of Pediatrics named after John Paul II in Sosnowiec. The Center of Pediatrics is one of the leading medical institution in Silesian Voivodship in Poland. The purposes of research were to study the positions of the Center of Pediatrics in the national ratings, to reveal the reasons of de-

(C) Nadiya Dubrovina, Andrzej Siwiec, Vira Dubrovina, Oksana Tulai, 2020.

Dubrovina Nadiya, CSc., PhD, Associate Professor at Department of Economics and Finance, School of Economics and Management of Public Administration in Bratislava, Slovakia. ORCID: 0000-00031346-9708, Email: nadiya.dubrovina@gmail.com

Siwiec Andrzej, PhD, Center of Pediatrics named after John Paul II in Sosnowiec, Poland. Email: sivietz@wp.eu

Dubrovina Vira, Senior Lecturer at Department of International Business, Finance and Accounting, Kharkiv Institute of Trade and Economy of KNTEU, Ukraine. ORCID: 0000-0001-6104-1138, Email: v.dubrovina@knute.edu.ua

Tulai Oksana, Doctor of Economics, Professor at Department of Finance named after S. I. Yuriy, West Ukrainian National University, Ukraine. ORCID: 0000-0002-5588-7046, Email: oksana.tulai@gmail.com
\end{abstract}


creasing evaluation of the Center of Pediatrics according to the different criteria, to provide initial sociological research of medical staff and to develop the essential recommendations for the improvement of positions of the Center of Pediatrics in the national ratings. For the analysis of the strategic positions of the Center of Pediatrics according the different criteria the results of national rating of leading medical institutions in Poland during period of 2015-2018 were used. We revealed that during last years the strategic positions of the Center of Pediatrics was dropped and the main reasons in the losses of positions were essentially decrease in the component "Management» and "Quality of care». In this issue we focused on the problem of improvement of human resources management in mentioned organization. According to the provided initial sociological research we revealed the needs and values of the different categories of personnel and developed complex of measures for Strategic Development Program which increases efficiency of the Center of Pediatrics over next 5 years. This Program allows improve competitiveness of this organization and its strategical positions in the national ratings of leading medical institutions in Poland.

\section{Key words:}

strategic position, medical organization, human resources management.

JEL: I11, L21, M12.

\section{Literature review}

The strategic management of human resources in a medical organization is one of the most important components of the medical organization development strategy. The features of the strategic management and some applications in healthcare institutions have been considered in the articles and monographs prepared by various authors (Swayne et al., 2006; Kabene et al., 2006; HassSymotiuk, 2011; Nica, 2013). Strategic management in general and strategic management of human resources, in particular, in medical organizations began to be applied relatively recently only 20-30 years ago (Miles \& Snow, 1984; Wright et al., 2005; Armstrong, 2006; Armstrong \& Taylor 2017; Mathias \& Jackson, 2006; Boxall \& Purcell, 2008). Moreover, the first projects related to the im- 
plementation of strategic management in the healthcare system were mainly implemented in the United States, where conditions were created for high competition in the medical services market and large national medical corporations and international networks of medical and pharmaceutical companies appeared (Swayne et al., 2006; Stępniewski, 2009; Hass-Symotiuk, 2011). Nevertheless, in countries in transition or post socialist countries the development of human resources management had started later, less than 10-15 years ago, as result of crucial reforms in healthcare after joining these countries to the EU (Nica, 2013; Tucmeanu, 2014). Thus, mentioned authors described the typical problems in healthcare for post socialist countries on example of Romania such as: migration of health workers, lack of funding and low salaries for medical staff, corruption, absence of patient-oriented approach and low level of satisfactions of the patients. In paper presented by E. Nica (2013), the author describes the complex linkages between employees' perceptions of human resources systems and hospital performance discusses the mechanisms through which human resources management can enhance patient satisfaction in health care organizations. Tucmeanu (2014) argues the impact of the health financing system on the use of services and weaknesses in equity and efficiency in public expenditure on health services, that confirms the imperfections in the health care market. Another researcher, R. Vulcanescu (2014) emphasizes the development of economic evaluations of public health in recent years and analyzes the relative value of public health outcomes in Romania and other countries in transition. He also discusses about dynamics of relevant public health behaviors, the importance of increasing and consolidation of these phenomena. Other important problem for modern organizations in different branches and in healthcare particularly is business ethics and social responsibility, perceived organizational support in employee-organization connections (Nicolaescu, 2013; Nica, 2016). These peculiarities should be taken into account for the development of human resources management in healthcare organizations, especially in countries - new members of the EU.

In our research, we focused on the analysis of the development of healthcare in other post socialist country, in Poland, and described the impact of reforms in healthcare on the significant changes in organizational and human resources management in the hospitals and other medical institutions in Poland.

With the period of preparation for Poland's joining to the EU, structural reforms, and the introduction of a health insurance system, the situation in the country's healthcare system began to improve gradually (Ustawa z dnia 30 sierpnia 1991 r. o zakladach opieki zdrowotnej). Many medical institutions were enlarged, restructured; attention began to be paid to methods of improving the efficiency of medical institutions, and to control the flow and use of financial resources (Stępniewski, 2009; B. Detyna \& J. Detyna, 2011; Kiliková \& Jakušová, 2016; Ondruš \& Ondrušová, 2017). And after joining the EU Poland began to study in sufficient detail the experience of other countries, introduced various training programs for medical personnel, a training system for healthcare organi- 
zations managers, elaborated the corporate code rules and high organizational culture in many medical institutions, also began to pay great attention the image of the medical institutions, to the quality of treatment and to the assessment of conditions on hospital and clinics on the part of patients (Stępniewski, 2009).

Significant changes have occurred in the system of training medical personnel; recognized international standards for patient care have been introduced; doctors have the opportunity to intern abroad or conduct research at leading medical institutes; a system of higher medical education for nurses and a number of other medical specialties was introduced; non-state medical schools have appeared to train a number of specialists in medical and other close social areas; non-governmental and private medical organizations, companies, centers arose that attracted highly qualified medical personnel and provided high-quality medical services (Ustawa z dnia 5 lipca 1996 r. o zawodach lekarza, pielęgniarki i położnej). Well-known international companies and concerns entered the domestic pharmaceutical market; serious investors have appeared who are ready to finance promising projects in medicine and pharmacy; a number of health care projects began to be funded from EU funds; reforms related to financing of medical institutions and expansion of powers of local authorities and self-government were carried out. Thus, the challenges arose that led to the need to introduce strategic management in various large and medium-sized state and non-state medical organizations in Poland (Korpalska, 2015).

An important factor in the development of mechanisms for improving the medical organizations management was the active extension of the medical services market in Poland and strong competition between leading medical institutions (Korpalska, 2015; Centrum Monitorowania Jakosci w Ochronie Zdrowia [CMJOZ], 2015, 2016, 2017, 2018). It should be mentioned, that the rating method is used often enough to assess the competitive position of enterprises, to assess the financial stability of financial institutions (banks and insurance companies), to assess the quality of personnel management in various organizations, etc. (Armstrong, 2006, 2017).

During last decade the periodical evaluation of the strategical positions of the leading medical institutions and analysis of their quality was provided by PZU Group, media agencies, experts, and others (Hass-Symotiuk, 2011; B. Detyna \& J. Detyna, 2011; Korpalska, 2015; CMJOZ, 2015, 2016, 2017, 2018). For the comparative analysis of the different strategical positions of leading medical institutions according to the different criteria the experts' opinions and ratings are often used. The essence of this approach is that recognized independent experts evaluate or rank the studied objects on the basis of various criteria using quantitative or qualitative indicators (CMJOZ, 2015, 2016, 2017, 2018). Estimates or points are summarized according to various criteria with account for weighting factors and determined in points or in other quantitative units the final position of the object under study. The research objects are ordered in accordance with the 
values of their totals and then their ordinal position in the ranking (position) is determined.

The Center of Pediatrics is one of the fundamental medical institution with specialization of pediatrics in the Silesian Voivodship and this Center took part in the annual evaluation and rating provided by PZU Group. Nevertheless, during last years the positions of the Center of Pediatrics were decreased in the ratings and the problem of study the situation in this health institution and improvement of the positions in the national ratings are occurred.

\section{Problem statement and methodology of study}

The aim of research was to study the positions of the Center of Pediatrics named after John Paul II in Sosnowiec in the national ratings of leading medical institutions provided by PZU Group, to reveal the reasons of decreasing evaluation of the Center of Pediatrics according to the different criteria, to provide initial sociological research of medical staff in the Center of Pediatrics and to develop the essential recommendations for the improvement of positions of the Center of Pediatrics in the national ratings. As data we used results of the evaluation of the positions of the Center of Pediatrics in the national ratings provided by PZU Group during period of 2015-2018, documents and reports of the Center of Pediatrics, results of the survey of the representatives of the different categories of medical staff. For this research we used quantitative and qualitative methods such as comparative analysis, synthesis, system approach, basic statistics.

\section{Main results and findings}

The Center of Pediatrics named after John Paul II in Sosnowiec (Center of Pediatrics) is a leading medical institutions with specialization of pediatrics in the Silesian Voivodship (Korpalska, 2015, Statistics Poland, 2018). This Center was established on the basis of two children's hospitals that have long existed in Sosnowiec: Hospital No. 3 with general pediatric profile and Hospital No. 6 rheumatologic profile.

The establishment of the Center of Pediatrics took place in the second half of 1996. Under the resolution of the Marshal's Office in Katowice, a general renovation of the «old» building was carried out and a third wing of the building was added. The Pediatric Center also includes a pediatric surgery department transferred from hospital No. 1 in Sosnowiec. In April 1999, after consultation 
with the church authorities of the SP ZOZ, the Center of Pediatrics was named after John Paul II. From the very beginning, the Center of Pediatrics has been developing extremely dynamically. For 15 years, new departments, studios and clinics have been constantly emerging in it to provide the most comprehensive medical care possible. Throughout this time, in the Center personnel also takes care about constant improving the quality, standards, qualifications of our staff, and about equipping the Hospital with modern medical devices and constant modernization of equipment - all in the name of the best services for our little patients. The Anesthesiology and Intensive Care Unit for Newborns and Children is a highly specialized unit that treats children in life-threatening conditions.

In the scope of the Medical Entity Center of Pediatrics - the medical activity division, the Center operates in three main enterprises and additional departments: a hospital; a day care center; out-patient health services and additional departments (Dubrovina et al., 2019).

As we mentioned above, despite to the serious achievements in the capacities and healthcare activities in the Center of Pediatrics this institution demonstrated the tendency to decrease the strategical positions in the national ratings of leading medical institutions in Poland. Thus, it is need to reveal the possible reasons and weaknesses of the Center of Pediatrics during last years.

For this task we studied the methodology of evaluation of leading medical institutions in Poland provided by PZU Group and analyzed the positions of the Center of Pediatrics according to the different criteria.

As we noted earlier, ratings and rankings are often used to analyze the strategic positions of medical organizations and compare them with the positions of other medical organizations. As well as, ratings are often used to evaluate the effectiveness of medical organizations.

In particular, over the past few years, PZU Group has been evaluating leading medical organizations in Poland, publishing these results in the press and posting on various websites. Evaluation is carried out according to the following criteria, such as: management $(\mathrm{Z})$, quality of medical care $(\mathrm{IO})$, medical service (OM), level and qualification of medical personnel, etc. The weighted average method is used to formulate the final grade based on various criteria.

More detailed description of this method and a scheme for calculating the final indicator are proposed by the author in Fig 1. Fig. 2.

The formation of such an indicator as the quality of care is presented in

The structure an indicator, that characterizes the quality of care is presented in Fig. 3.

Next, it should be analyzed the strategic positions by the final indicator and its individual components for the Center of Pediatrics named after John Paul II in 
Sosnowiec. For comparison, we will use the analysis of the dynamics and positions of the final indicators of Center of Pediatrics over the past few years, as well as a comparative assessment of the individual components for this center compared to several leading pediatric centers in Poland and compared to some medical centers in the Silesian Voivodship.

\section{Figure 1}

The elements for the evaluation of component «Management»

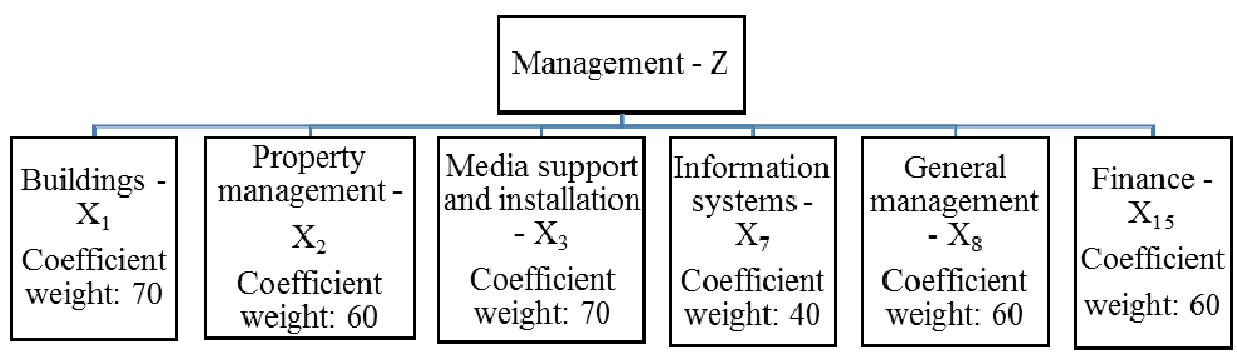

Source: created by authors based on the methodology for rating leading hospitals in Poland (Available at: https://www.cmj.org.pl/ranking/wyniki)

\section{Figure 2}

The elements for the evaluation of component «Quality of care»

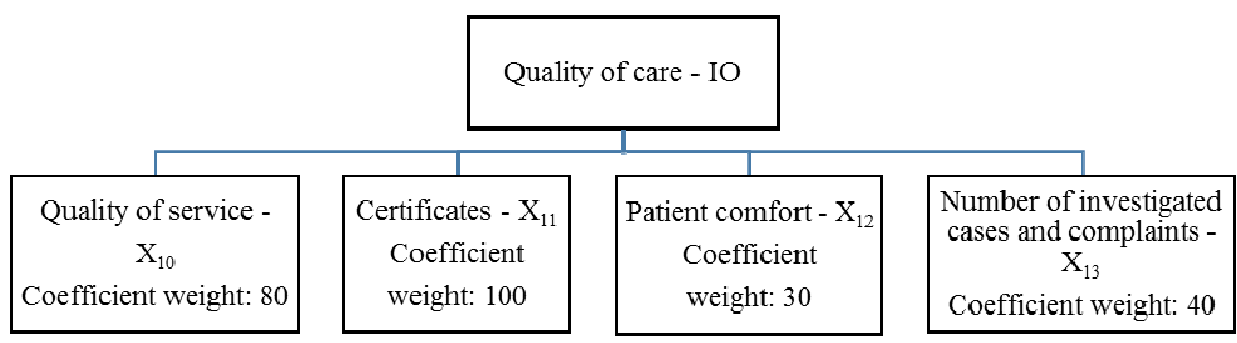

Source: created by authors based on the methodology for rating leading hospitals in Poland (Available at: https://www.cmj.org.pl/ranking/wyniki) 
Figure 3

The elements for the evaluation of component «Healthcare (medical service)»

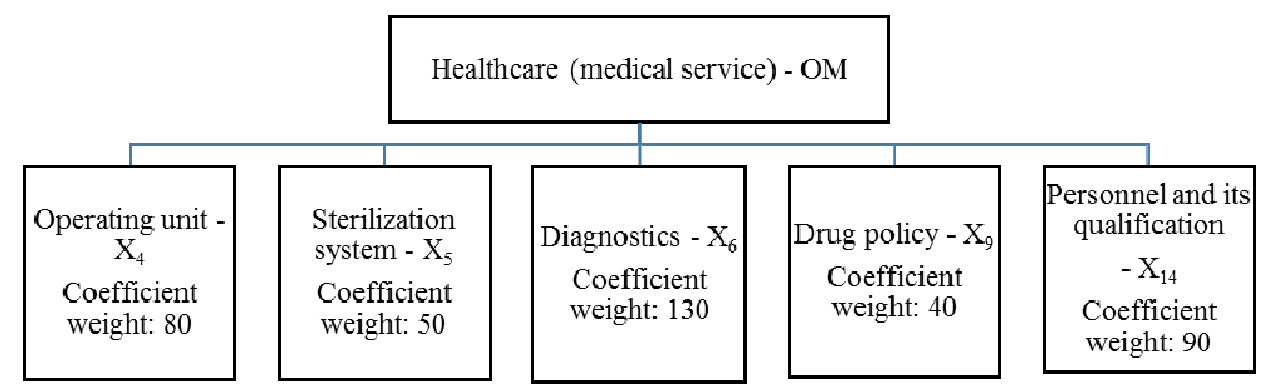

Source: elaborated by authors based on the methodology for rating leading hospitals in Poland (Available at: https://www.cmj.org.pl/ranking/wyniki)

Thus, the evaluation $Z_{i}$ of the $Z$ (management) for the i medical institution is calculated by formula:

$$
Z_{i}=70 \cdot x_{1 i}+60 \cdot x_{2 i}+70 \cdot x_{3 i}+40 \cdot x_{7 i}+60 \cdot x_{8 i}+60 \cdot x_{15 i},
$$

where $0 \leq x_{j i}, i$ - number of the hospital (medical center); variables $x_{1}, x_{2}, x_{3}$, $x_{7}, x_{9}, x_{15}$ means the experts' evaluation such characteristics as: Buildings; Property management; Media support and installation; Information systems; General management; Finance.

It is should be noted that according to the methodology prepared by PZU Group the evaluation $Z_{i}$ do not exceed 360 , or the $\max Z=360$.

In the similar way the other evaluations calculated by formulas. by formula:

For example, $1 O$ (quality of care) for the $i$ medical institution is calculated

$$
I O_{i}=80 \cdot x_{10 i}+100 \cdot x_{11 i}+30 \cdot x_{12 i}+40 \cdot x_{13 i},
$$

where $0 \leq x_{j i} \leq 1, \mathrm{i}$ - number of the hospital (medical center); variables $x_{10}, x_{11}$, $x_{12}, x_{13}$ means the experts' evaluation such characteristics as: Quality of service; Certificates; Patient comfort; Number of investigated cases and complaints.

It is should be noted that according to the methodology prepared by PZU Group the evaluation $\mathrm{IO}_{i}$ do not exceed 250, or the $\max I O=250$.

Indicator $O M$ (healthcare or medical service) counted as: 


$$
O M_{i}=80 \cdot x_{4 i}+50 \cdot x_{5 i}+130 \cdot x_{6 i}+40 \cdot x_{9 i}+90 \cdot x_{14 i},
$$

where $0 \leq x_{j i} \leq 1, \mathrm{i}-$ number of the hospital (medical center); variables $x_{4}, x_{5}, x_{6}$, $x_{9}, x_{14}$ means the experts' evaluation such characteristics as: Operating unit; Sterilization system; Diagnostics; Personnel and its qualification.

It is should be noted that according to the methodology prepared by PZU Group the evaluation $O M_{i}$ do not exceed 390, or the $\max O M=390$.

In table 1 an analysis of the ranking results of some medical centers is presented. We choose the medical institutions specialized in health care services for children in Poland and included in ranking, and medical institutions in Silesian Voivodship which were included in ranking too. The specialized medical institutions for children in Poland are the objects for the evaluation of the position of the Center of Pediatrics among other similar centers. But we also need to evaluate the position of the Center of Pediatrics among other medical institutions in Silesian Voivodship, because some of the wards or departments of these medical institutions can offer medical services for children too.

Ranking of hospitals «Safe Hospital 2018» includes 11 medical centers, located not only in the Silesian Voivodship and presented in table 1 by place in the ranking. Place in the ranking is determined according to the total value of the points. The presented rating includes 9 medical centers located in the Silesian Voivodship, one medical center from Kuyavian-Pomeranian Voivodship and 1 medical organization from Warmian-Masurian Voivodeship. As can be seen from the table 1, the highest place in the ranking (6th position) is occupied by Niepubliczny Zakład Opieki Zdrowotnej Lecznica Dzieci i Dorosłych Szpital im. I. Mościckiego Sp., that is located in the Silesian Voivodeship.

\section{Table 1}

Ranking of medical centers in «Safe Hospital 2018»

\begin{tabular}{|c|c|c|c|c|c|}
\hline \multirow{2}{*}{$\begin{array}{l}\text { Number } \\
\text { in the } \\
\text { ranking }\end{array}$} & \multirow{2}{*}{ Name of medical institution } & \multirow{2}{*}{$\begin{array}{l}\text { Total } \\
\text { points }\end{array}$} & \multicolumn{3}{|c|}{ Evaluation of indicators (points) } \\
\hline & & & Management & $\begin{array}{l}\text { Quality } \\
\text { of care }\end{array}$ & $\begin{array}{l}\text { Healthcare } \\
\text { (medical } \\
\text { service) }\end{array}$ \\
\hline 6 & $\begin{array}{l}\text { Niepubliczny Zakład Opieki } \\
\text { Zdrowotnej Lecznica Dzieci i } \\
\text { Dorosłych Szpital im. I. Mo- } \\
\text { ścickiego Sp. } \\
\text { (Silesian Voivodship) }\end{array}$ & $\begin{array}{c}860,57 \\
878 \\
(2017)\end{array}$ & 334,94 & 149,45 & 376,19 \\
\hline 18 & $\begin{array}{l}\text { Wojewódzki Szpital Specjal- } \\
\text { istyczny nr } 5 \text { im. Św. Barbary w } \\
\text { Sosnowcu } \\
\text { (Silesian Voivodship) }\end{array}$ & $\begin{array}{l}825,2 \\
848 \\
(2017)\end{array}$ & 272,34 & 193,7 & 359,16 \\
\hline
\end{tabular}


Analysis of the strategic positions of Center of Pediatrics: the problem of improvement of human resources management

\begin{tabular}{|c|c|c|c|c|c|}
\hline \multirow{2}{*}{$\begin{array}{l}\text { Number } \\
\text { in the } \\
\text { ranking }\end{array}$} & \multirow[b]{2}{*}{ Name of medical institution } & \multirow{2}{*}{$\begin{array}{l}\text { Total } \\
\text { points }\end{array}$} & \multicolumn{3}{|c|}{ Evaluation of indicators (points) } \\
\hline & & & Management & $\begin{array}{l}\text { Quality } \\
\text { of care }\end{array}$ & $\begin{array}{l}\text { Healthcare } \\
\text { (medical } \\
\text { service) }\end{array}$ \\
\hline 22 & $\begin{array}{l}\text { Wojewódzki Szpital Dziecięcy } \\
\text { im. J. Brudzińskiego w } \\
\text { Bydgoszczy } \\
\text { (Kuyavian-Pomeranian Voivod- } \\
\text { ship) }\end{array}$ & $\begin{array}{c}822,9 \\
- \\
(2017)\end{array}$ & 258,05 & 190,51 & 374,33 \\
\hline 28 & $\begin{array}{l}\text { Wojewódzki Specjalistyczny } \\
\text { Szpital Dziecięcy im. prof. } \\
\text { Stanisława Popowskiego w } \\
\text { Olsztynie } \\
\text { (Warmian-Masurian Voivode- } \\
\text { ship) }\end{array}$ & $\begin{array}{c}816,89 \\
817 \\
(2017)\end{array}$ & 266,02 & 185,27 & 365,6 \\
\hline 53 & $\begin{array}{l}\text { Szpital Rejonowy im. dr. Józefa } \\
\text { Rostka w Raciborzu } \\
\text { (Silesian Voivodship) }\end{array}$ & $\begin{array}{c}778,13 \\
787 \\
(2017)\end{array}$ & 247,25 & 182,71 & 348,17 \\
\hline 66 & $\begin{array}{l}\text { Zagłębiowskie Centrum Onko- } \\
\text { logii Szpital Specjalistyczny im. } \\
\text { Sz. Starkiewicza w Dąbrowie } \\
\text { Górniczej (Silesian Voivodship) }\end{array}$ & $\begin{array}{c}763,8 \\
793 \\
(2017)\end{array}$ & 232,17 & 196,44 & 335,19 \\
\hline 70 & $\begin{array}{l}\text { Wojewódzki Szpital Specjal- } \\
\text { istyczny nr } 2 \\
\text { (Silesian Voivodship) }\end{array}$ & $\begin{array}{c}760,01 \\
794 \\
(2017) \\
\end{array}$ & 221,32 & 185,12 & 353,58 \\
\hline 72 & $\begin{array}{l}\text { Centrum Pediatrii im. Jana } \\
\text { Pawła II w Sosnowcu } \\
\text { (Silesian Voivodship) }\end{array}$ & $\begin{array}{c}758.7 \\
782 \\
(2017)\end{array}$ & 237,24 & 199,1 & 322,36 \\
\hline 74 & $\begin{array}{l}\text { Górnośląskie Centrum Me- } \\
\text { dyczne im. prof. Leszka Gieca } \\
\text { Ślaskiego Uniwersytetu Me- } \\
\text { dycznego w Katowicach (Sile- } \\
\text { sian Voivodship) }\end{array}$ & $\begin{array}{c}754,88 \\
749 \\
(2017)\end{array}$ & 238,32 & 183,21 & 333,35 \\
\hline 80 & $\begin{array}{l}\text { Górnośląskie Centrum Zdrowia } \\
\text { Dziecka im. św. Jana Pawła II } \\
\text { Samodzielny Publiczny Szpital } \\
\text { Kliniczny nr } 6 \text { Śląskiego Uni- } \\
\text { wersytetu Medycznego w Ka- } \\
\text { towicach } \\
\text { (Silesian Voivodship) }\end{array}$ & $\begin{array}{c}749,72 \\
792 \\
(2017)\end{array}$ & 223,28 & 166,23 & 360,21 \\
\hline 98 & $\begin{array}{l}\text { Zespół Zakładów Opieki } \\
\text { Zdrowotnej } \\
\text { (Silesian Voivodship) }\end{array}$ & $\begin{array}{c}732,11 \\
748 \\
(2017)\end{array}$ & 189,51 & 169,78 & 372,82 \\
\hline
\end{tabular}

Source: developed by authors based on the data for rating leading hospitals in Poland (Available at: https://www.cmj.org.pl/ranking/wyniki_2018) 
For this medical center, namely, Niepubliczny Zakład Opieki Zdrowotnej Lecznica Dzieci i Dorosłych Szpital im. I. Mościckiego Sp. , the total score for the rating was 860,57 in 2018 and 878 in 2017 . It means, that over the year there is a decrease in the overall score by 17,43 points. Also, this medical center scored the most points for such components as management and healthcare. The medical center with the lowest number of points is Zespół Zakładów Opieki Zdrowotnej, that is also located in the Silesian Voivodship. This medical center occupies 98th position in the ranking and scored 732,11 points in total, significantly inferior to other medical centers in management. However, this center has high scores for such components as quality of care and healthcare (medical service).

Further, we analyzed the strategic positions of the Center of Pediatrics named after John Paul II in Sosnowiec. According to the rating for 2018, the Center occupies 72 positions in the general list. The total number of points in the final assessment in 2018 was 758,7 and 782 in 2017. At the same time, the Center scored the highest number of points among other medical organizations in terms of quality of care $(199,1)$, that characterizes high level of quality of service, patient comfort and many certificates received. In terms of management components and healthcare the Center takes middle positions in 2018. So, for management $-237,24$ and for healthcare $-322,36$. In particular, in terms of management indicators, the Center is significantly inferior to the rating leader - by 97,7 points.

In order to study the strategic positions of the Center, it is necessary to analyze its rating over the past 4 years, which will reveal trends in its development and make it possible to formulate recommendations for improving its position in the ranking of medical centers in Poland. It should be mentioned, that for the study period, the best positions of the Center in the ranking of medical centers of Poland were in 2015, namely 52 place in the general list.

In 2016-2017 the Center reduced its position to 77th in the ranking and in 2018 , we are seeing an increase to 72 th position. At the same time, the total number of points ranged from 758,7 in 2018 to 811,18 in 2015 .

In Fig. 4 the positions of the Center of Pediatrics named after John Paul II in Sosnowiec are presented during period of 2015-2018.

As we can see from Fig. 4 the total scores for the Center of Pediatrics were essentially decreased over period of 2015-2018. During 2015-2016 this estimation was reduced more than 3\%, from 811,18 in 2015 till 786 in 2016. During 2016-2017 the values of total scores were stable, but in 2018 the total score was dropped again till 758,7 or $5 \%$ in comparison with 2017 . During period $2015-2018$ the total score reduced on $6,5 \%$. If in 2015 the Center of Pediatrics occupied position on 52 place, in 2018 the position of the Center of Pediatrics was 72, it means that the Center losses was 20 places in rating. 
Figure 4

The dynamics of total scores for the Center of Pediatrics

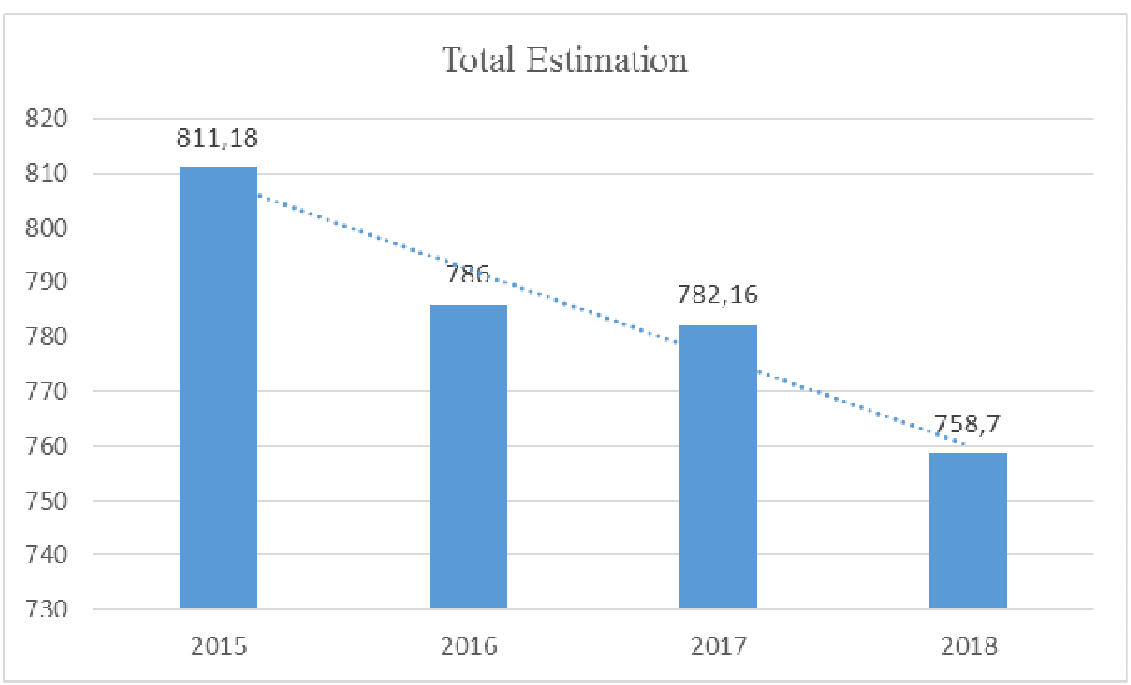

Source: own elaboration based on the data for the Center of Pediatrics in rating leading hospitals in Poland

The reasons, which led to negative trend in positions of the Center of Pediatrics were important. In Fig. 5 the dynamics of components of total scores for the Center of Pediatrics is presented.

As we can see from this graph the main reasons in the losses of positions were essentially decrease in the component «Management» and "Quality of care». In 2015 the estimation for the component «Management» was 296,15, but in 2018 it reduced till 237,24, it means that reduce was $20 \%$. The estimation for the component "Quality of care» decreased from 220,28 in 2015 till 199,1 in 2018 or more than $9 \%$.

Thus, we can conclude that it is important to increase the quality of management due to the improvement of decision making processes and more productivity of administrative staff, better control for financial state and actualization of the information system. Also it is necessary to improve the component "Quality of care", where the attention should be paid to the enhancement of the quality of services and comfort conditions for patients, to increase the number of certificates and awards and to reduce the number of complaints. 
Figure 5

The dynamics of components of total scores for the Center of Pediatrics

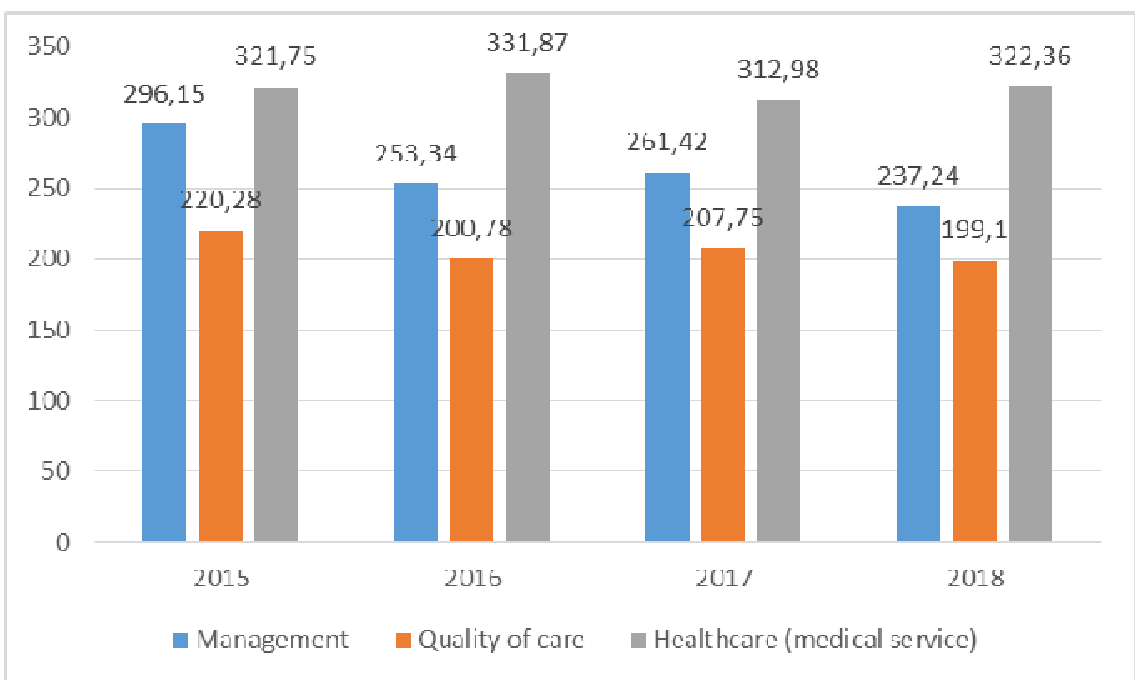

Source: own elaboration based on the data for the Center of Pediatrics in rating leading hospitals in Poland

For this objective it is important to improve the qualitative characteristics of the personnel in the Center of Pediatrics and to develop the program for the strategical management of human resources in this medical organization.

In regards with development of the strategical management of human resources in the Center of Pediatrics it is necessary to understand better the needs and values of the personnel in this organization. Due to this reason we developed a questionnaire and conducted initial survey for the different representatives of medical staff in the Center of Pediatrics. Some of the questions were related to assessing the external environment in which the health system operates in Poland, some questions were related to assessing the quality of medical care in Poland, and some questions were related to motivation methods staff and organizational culture. In the survey 36 people took part, of which: 12 doctors $(33,3 \%)$ and 24 people $(66,7 \%)$ - other representatives of the medical staff (nurses - 22 people, 1 - paramedic, 1 - medical technician, electro-radiologist). Thus, representatives of various departments of the Center of Pediatrics took part in the survey, $83 \%$ of the doctors were pediatricians, and $75 \%$ of the doctors had additional specialization. Among respondents $28 \%$ had a secondary education, 26 people had a higher education of the first or second level. The average 
age of the respondents was 41 years; respondents from 25 to 56 years old took part in the survey. A fairly large number of young specialists were represented, with work experience up to 5 years (22.5\% of the sample), as well as the number of medical specialists with work experience over 25 years (27 8\%).

Table 2 shows the distribution of respondents according to the degree of satisfaction with the quality of medical services in terms of two positions: as medical personnel and as a patient.

Table 2

Distribution of respondents according to the degree of satisfaction with the quality of medical services

\begin{tabular}{|c|c|c|c|c|}
\hline \multirow{2}{*}{ Level of quality of medical care } & \multicolumn{2}{|c|}{ As medical worker } & \multicolumn{2}{c|}{ As a patient } \\
\cline { 2 - 5 } & Frequency & $\%$ & Frequency & $\%$ \\
\hline «Low» & 7 & 19,4 & 6 & 16,7 \\
\hline «Medium» & 23 & 63,9 & 24 & 66,7 \\
\hline «High» & 6 & 16,7 & 6 & 16,7 \\
\hline
\end{tabular}

Source: own elaboration based on the results from survey of respondents

As can be seen from the data in this table, more than $60 \%$ of respondents rate the quality of medical services as «average" and more than $16 \%$ of respondents rate the quality of medical services as «high». At the same time, there was no significant difference between the answers of the respondents, both from the point of view of the medical worker and from the point of view of the patient. With regard to assessing the quality of medical care in Sosnowiec, 8 people (or $22,2 \%)$ are completely satisfied with the quality, 20 people $(55,5 \%)$ are most likely satisfied with the quality, i.e. evaluate how as «average» level and 8 people $(22,2 \%)$ are not satisfied, i.e. rated as «low» level. Comparison of these results differs from the respondents' assessment of the quality of medical services in general in Poland. So, in comparison with assessments of the quality of medical services in Poland, for the case of Sosnowiec there was a slightly higher percentage of respondents who rated the quality of medical services as «low», however, there was also a higher percentage of respondents who rated the quality of medical services as «high».

Apparently, the level of the medical institution itself, the competence of medical specialists, as well as the positive or negative experience in receiving certain medical services as a patient, play an important role in assessing the quality of medical services in Sosnowiec. Among 36 respondents who partici- 
pated in the survey, 24 respondents $(66,7 \%)$ believe that medical services are available to all segments of the population in state medical institutions, and 12 people (33.3\%) believe that only those who have a medical insurance. Regarding the degree of accessibility of medical services in non-state medical institutions, 5 respondents $(13,9 \%)$ consider that medical services in non-state medical institutions are accessible to all segments of the population; 19 respondents $(52,8 \%)$ believe that medical services in non-governmental medical institutions are accessible to middle-income and high-income people, and 12 respondents $(33,3 \%)$ believe that medical services in non-governmental medical institutions are available to high-income people. When we asked about the assessment of the need to introduce compulsory health insurance in Poland, the respondents' opinions were as follows: 16 respondents $(44,4 \%)$ believed that the introduction of compulsory health insurance was necessary, 14 respondents $(38,9 \%)$ believed that the introduction of compulsory health insurance was most likely necessary and 6 respondents $(16,7 \%)$ believed that there was no need to introduce compulsory health insurance. Thus, more than $80 \%$ of respondents believed that compulsory medical insurance of the population in Poland was necessary or, most likely, necessary.

Concerning the question related to the attitude of respondents to the development of private and/or commercial medicine, the opinions of respondents were distributed as follows: 25 respondents $(69,4 \%)$ spoke in favor of development of commercial medicine; 4 respondents $(11,1 \%)$ considered that all medical institutions should be state-owned; 7 respondents $(19,4 \%)$ believed that it is necessary to reduce part of commercial medical centers. When we asked which of the listed medical services should be paid, the respondents' opinions were distributed as follows (table 3).

Table 3

Distribution of opinions of respondents about the need for paid medical services

\begin{tabular}{|l|c|c|}
\hline $\begin{array}{c}\text { What medical services in your opinion, should } \\
\text { be paid by the population }\end{array}$ & Frequency & $\%$ \\
\hline emergency medical care & 0 & 0 \\
\hline call of a doctor or ambulance at home & 14 & 38,9 \\
\hline consultation of the doctor in the clinic & 15 & 41,7 \\
\hline hospital stay & 5 & 13,9 \\
\hline diagnostic services, analyses & 9 & 25 \\
\hline pharmaceuticals & 17 & 47,2 \\
\hline
\end{tabular}

Source: own elaboration based on the results from survey of respondents 
As we can see from the data presented in the table 3 , all respondents believe that emergency medical care should be free, while other services may be paid. However, less than $50 \%$ believe that the medical services listed in the table 3 should be paid. Concerning the question regarding the opening and running of their business in health care industry, the respondents answered as follows: 1 respondent $(2,8 \%)$ is ready to receive a second special higher education (economic or legal education) for this; 24 respondents $(66,7 \%)$ would hire an accountant or manager to manage their business and 11 respondents $(30,6 \%)$ would manage their own business.

The distribution of opinions of the respondents was distributed regarding the degree of importance of the problems in public health in Poland is given in table 4.

Table 4

\section{Distribution of respondents' opinions on the degree of importance of health problems in Poland}

\begin{tabular}{|l|c|c|}
\hline \multicolumn{1}{|c|}{$\begin{array}{l}\text { Which of the listed problems of Poland medicine are } \\
\text { the most important }\end{array}$} & Frequency & $\%$ \\
\hline the fight against corruption & 6 & 16,7 \\
\hline low level of medicine financing & 35 & 97,2 \\
\hline Insufficient level of medical services quality & 8 & 22,2 \\
\hline $\begin{array}{l}\text { the necessity to improve the competence of medical } \\
\text { personnel, study advanced European experience }\end{array}$ & 7 & 19,4 \\
\hline health insurance reform & 12 & 33,3 \\
\hline health care reform & 13 & 36,1 \\
\hline
\end{tabular}

Source: own elaboration based on the results from survey of respondents

As can be seen from the data given in table 4, almost all respondents or 35 people $(97,2 \%)$ believe that the most important problem is insufficient financing of health care in Poland. More than one third of respondents indicate the need for reform, both in the health insurance system and in the medical services sector. More than $20 \%$ of respondents consider the problem of insufficient quality of medical services to be important, about the same number $(19,5 \%)$ indicate the need to increase the competence of medical personnel and the study of European experience; $16,7 \%$ of respondents consider that the fight against corruption in the healthcare sector to be important.

Table 5 shows the results of a survey of respondents regarding the wages (in euro) of various categories of medical staff. 
Table 5

The results of the survey of respondents regarding the wages (in euro) of various categories of medical staff

\begin{tabular}{|l|l|l|l|l|l|l|}
\hline \multirow{2}{*}{ Category } & \multirow{2}{*}{ Mean } & \multicolumn{2}{c|}{$\begin{array}{c}95 \% \text { confiden- } \\
\text { tial intervals }\end{array}$} & Median & Minimum & Maximum \\
\cline { 3 - 6 } & & Lower & Upper & & & \\
\hline nurse & 3411 & 3252 & 3571 & 3200 & 3000 & 5000 \\
\hline novice practitioner & 5308 & 4978 & 5638 & 5000 & 4000 & 10000 \\
\hline $\begin{array}{l}\text { novice doctor spe- } \\
\text { cializing in scientific } \\
\text { research (PhD stu- } \\
\text { dent) }\end{array}$ & 5783 & 5396 & 6171 & 5900 & 3500 & 10000 \\
\hline $\begin{array}{l}\text { doctor with experi- } \\
\text { ence of more than } \\
10 \text { years in the pro- } \\
\text { file of specialization }\end{array}$ & 8494 & 7498 & 9491 & 7450 & 6000 & 20000 \\
\hline family doctor (GP) & 7767 & 7159 & 8375 & 7100 & 6000 & 15000 \\
\hline surgeon & 9617 & 8363 & 10870 & 7900 & 7000 & 25000 \\
\hline Internist & 7650 & 6997 & 8303 & 6950 & 6000 & 15000 \\
\hline a doctor-specialist & 10164 & 7609 & 12719 & 7000 & 6200 & 50000 \\
\hline
\end{tabular}

Source: own elaboration based on the results from survey of respondents

As we can see from the above data, according to the respondents, the minimum wage of medical personnel should be at least 3 thousand euros for nurses and novice doctors, and the minimum wage of doctors with experience of more than 10 years should be at least 6 thousand euros. It can be seen from the survey that respondents estimate the level of salaries in healthcare according to the example of highly developed western countries of EU, while in Poland, according to statistics, the average salary in the industry is a little more than 1000 euros, and the real salaries of most doctors range from 2,5-3 thousand euros to 5 thousand euros. Therefore, the respondents' assessments are more consistent with their expectations, and not with the realities of the healthcare system in Poland. At the same time, to prevent the problem of outflow of personnel abroad, it is necessary to increase the salary of medical personnel, so that within 5 years, targets can be achieved.

When we asked about the cost of one consultation with a doctor, respondents believe that the minimum cost can be 20 zł (approx. 5 euro), and the maximum - $200 \mathrm{zł}$ (approx. 50 euro). The average cost of a consultation is 71 zloty (approx. 18 euro), the confidence intervals for the average value range 
from 55 zloty (approx. 14 euro) to 88 zloty (approx. 22 euro), and the median for the sample is 50 zloty (approx.12,5 euro).

For questions related to tuition at medical schools $86,1 \%$ of respondents indicated that the state should pay these costs, and $94,4 \%$ of respondents said that funds from the state budget should be the source of funding for medical schools. Regarding the respondents' opinions on the prospects for the development of the healthcare sector in certain areas (Table 6), the respondents noted that the most priority areas are narrow specializations $(58,3 \%)$ and pediatrics $(55,6 \%)$. More than $30 \%$ of respondents indicated that obstetrics and gynecology are also an important area of development; $27,8 \%$ of respondents also noted family medicine and surgery.

Table 6

Distribution of respondents' assessments characterizing the importance of the development of certain areas of health

\begin{tabular}{|l|c|c|}
\hline \multicolumn{1}{|c|}{ Area of specialization } & Frequency & $\%$ \\
\hline pediatrics & 20 & 55,6 \\
\hline family medicine & 10 & 27,8 \\
\hline therapy & 3 & 8,3 \\
\hline surgery & 10 & 27,8 \\
\hline obstetrics and gynecology & 11 & 30,6 \\
\hline narrow specializations & 21 & 58,3 \\
\hline
\end{tabular}

Source: own elaboration based on the results from survey of respondents

Among the respondents, $63,9 \%$ of respondents noted a high level of demand for their specialty in the labor market, while $52,8 \%$ considered the level of demand for their specialty in the labor market of medical specialists, and $47,2 \%$ of respondents rated the level of demand for their specialty in the labor market of medical specialists as «average».

In Fig. 6 the distribution of respondents' opinions on the question regarding the success of the doctor among patients is presented. So, 18 respondents $(50 \%)$ consider the factor "the ability to communicate with patients and inspire confidence" (Q23_1) to be important; 28 respondents $(77,8 \%)$ consider such a factor as «professionalism» to be important (Q23_2); 15 respondents $(41,7 \%)$ noted the importance of the factor «sociability, appearance, style of behavior» (Q23_3). 
Figure 6

The importance of factors determining the success of a doctor in patients

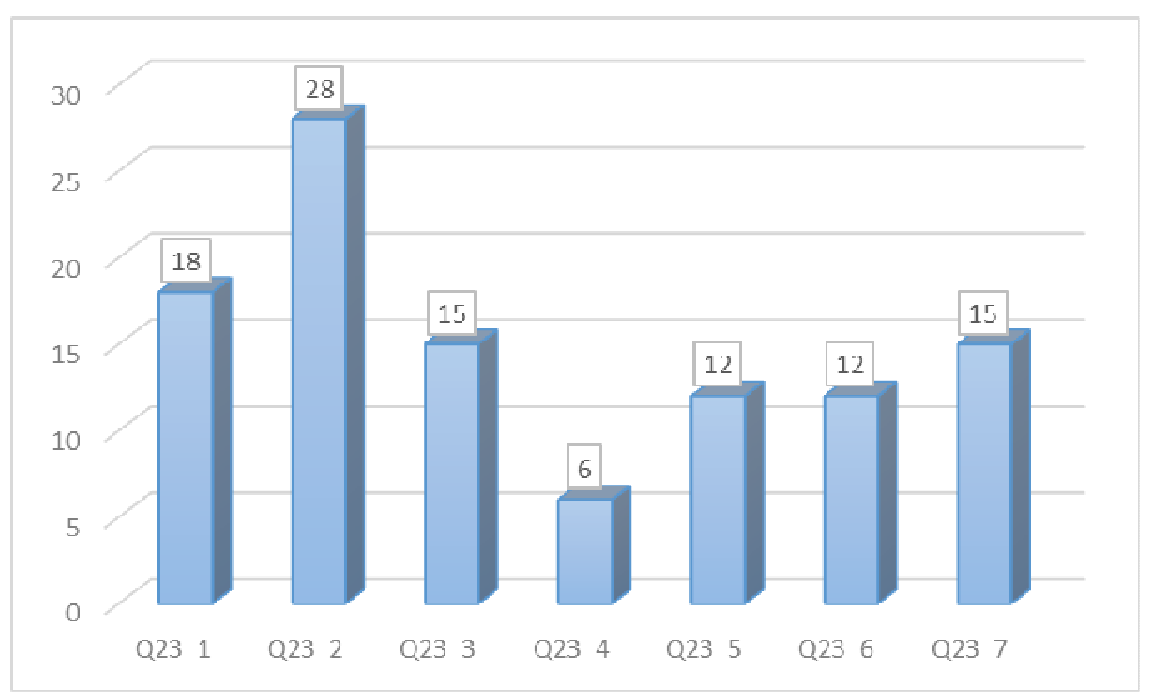

Source: own elaboration based on the results from survey of respondents

Only 6 respondents $(16,7 \%)$ indicated the factor «integrity, honesty» (Q23_4); 12 respondents $(33,3 \%)$ consider the factor «modesty, lack of intent to extort money from a patient» to be important (Q23_5); as much i.e. 33,3\% of respondents noted the factor «impeccable reputation» (Q23_6); and 15 respondents $(41,7 \%)$ indicated the factor «frequent recommendations of other doctors and or patients» (Q23_7). Thus, taking into account the opinion of respondents, the first place is occupied by such a factor as «professionalism», the second by the factor "the ability to communicate with patients and inspire confidence», the third and fourth place by the factors of "sociability, appearance, style of behavior» and "frequent recommendations of other doctors and or patients." When we asked the question related to the communications with a patient, in the opinion of all respondents, no additional knowledge in psychology and PR is required that needs to be studied in trainings or courses; 21 respondents $(58,3 \%)$ believe that enough general knowledge of deontology and 15 respondents $(41,7 \%)$ believe that practical experience in communications with people is necessary.

Concerning the question, what factors, according to the respondents, determine the choice of a doctor by them for themselves or their relatives, the respondents indicated the following factors (Fig. 7). 


\section{Figure 7}

\section{Factors that determine a doctor's choice}

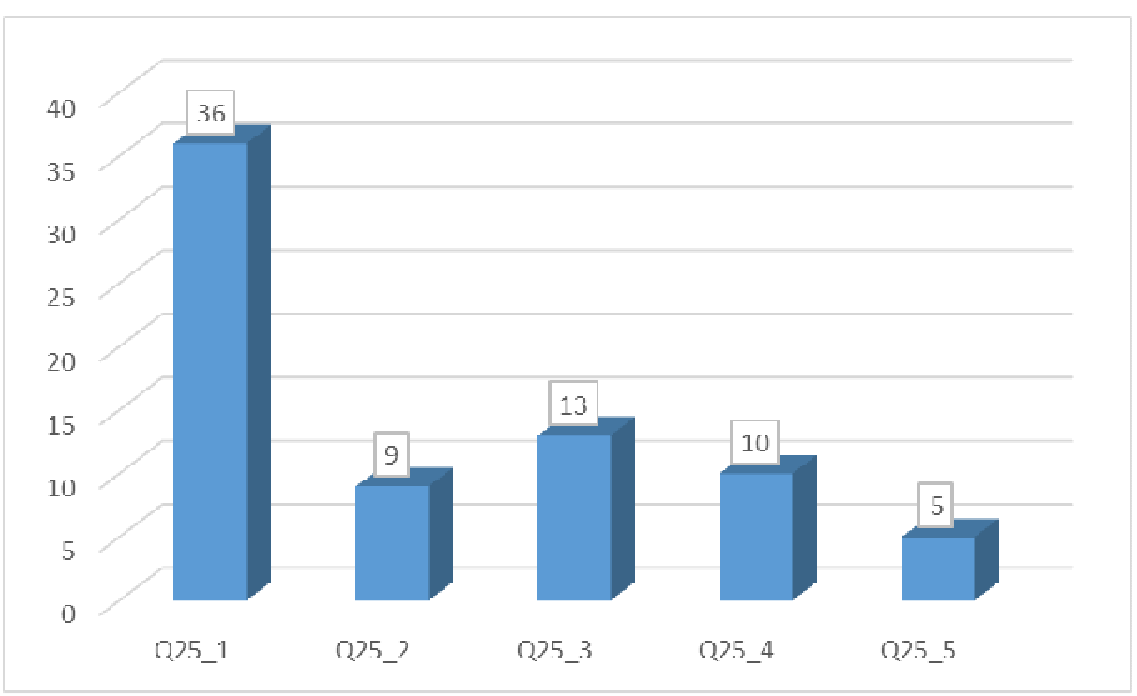

Source: own elaboration based on the results from survey of respondents

So, all 36 respondents noted such a factor as «the competence and professionalism of the doctor» (Q25_1); 9 respondents (25\%) indicated the factor "good attitude towards the patient" (Q25_2); 13 respondents $(36,1 \%)$ consider the factor «recommendations of friends and acquaintances» to be important (Q25_3).

Further, 10 respondents $(27,8 \%)$ indicated a factor such as «personal acquaintance or friendship» (Q25_4) and 5 respondents $(13,9 \%)$ noted a factor such as «relatively low cost of its services» (Q25_5). Thus, the main criterion for choosing a doctor is his or her competence and professionalism; however, the recommendations of friends and acquaintances are also important for more than one third of the respondents.

Respondents indicated that they regularly take part in post diploma education, usually every three to four years; some respondents undergo continuing education once every two years. Only 16 respondents took part in international and European projects, i.e. $44,4 \%$. At the same time, if doctors speak one or two foreign languages to varying degrees, the rest of the medical staff, for example nurses, indicated that they do not speak any foreign language. 
Over $88 \%$ of respondents use the Internet and email. However, to the question «How do you feel about the discussion of medical personal quality and professional characteristics of doctors by patients in various forums?» no one said that was positive. 10 respondents $(27,8 \%)$ indicated that it was negative; 22 respondents $(61,1 \%)$ are neutral about this issue and 4 respondents $(11,1 \%)$ have not decided on their opinion.

Respondents also assessed the level of importance of methods of motivating medical personnel and the results are presented in Fig. 8.

Figure 8

Factors determining the motivation of staff

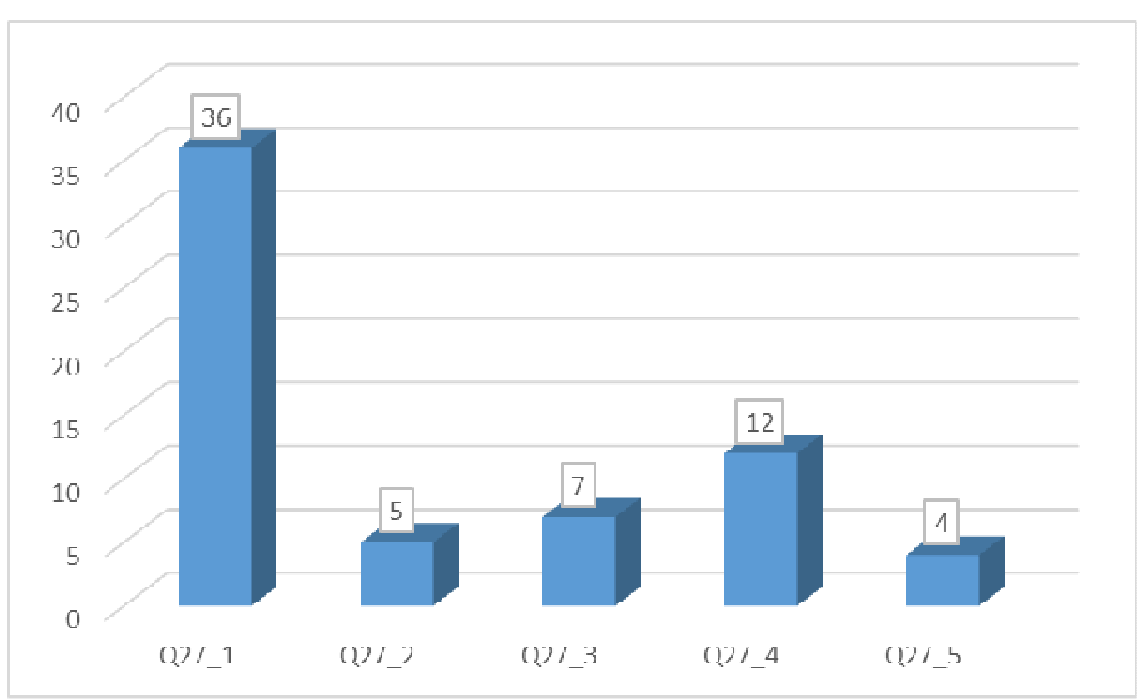

Source: own elaboration based on the results from survey of respondents

So, when we asked the question about the most important factors of motivation, all 36 respondents noted such a factor as "salary increase» (Q27_1); 5 respondents $(13,9 \%)$ indicated such factor as the provision of housing (Q27_2).

Further, 7 respondents $(19,4 \%)$ consider the factor "social benefits" to be important (Q27_3); 12 respondents (33,3\%) indicated a factor such as «promotion, category assignment» (Q27_4) and 4 respondents $(11,1 \%)$ noted a factor such as «receiving awards, diplomas» (Q27_5). Thus, the main criterion for staff 
motivation, according to all respondents, is an increase in wages, but career growth and obtaining a category and specialization are also important for more than one third of respondents. All other factors are less significant or important only for individual medical workers.

Thus, the questionnaire survey made it possible to assess the opinions of respondents regarding the assessment of the state of health care in Poland and its directions of development; the level of quality of medical services in general in Poland and in the city of Sosnowiec; identify the most important factors that determine the choice of a doctor and his success in patients; to assess the salary expectations for various categories of medical personnel and the degree of importance of certain factors affecting the motivation of the medical personnel.

As the analysis of human resources and results of the survey of personnel showed it is necessary to plan the trainings and workshops for the different categories of personnel and such complex of measures together with motivation of personnel will have impact on the development of human resources and quality of medical services in the Center of Pediatrics, that improve its position in the national rating of hospitals in Poland.

Based on an analysis of materials about the Center of Pediatrics, surveys of representatives of various departments of this organization, conversations with the director of the Center, we had concluded that Center has a set of ambitious plans of development in future. However, there are still many problems associated with the implementation of the strategic management of the organization, as a whole, and its human resources, in particular.

Thus, one of the objectives of the Center of Pediatrics is to develop a Strategic Development Program for the period 2020-2025, where the new program should eliminate the shortcomings and disadvantages of the previous Program, which was mostly declarative, was not structured enough. The previous Program did not contain SWOT analysis, did not involve the use of BSC (Balanced Scorecard) and KPI systems for evaluating the performance of each department or structural unit. In addition, the old strategic development program did not have a separate detailed section on the human resources management and planning in the Center of Pediatrics.

In respect with the development of BSC and KPI for Center of Pediatrics and evaluation of development of human resources with KPI system we proposed plan for Center of Pediatrics including such actions as: Seminar «Implementation of BSC and KPI in medical institutions» for target group «Board of directors, Chiefs of departments and wards»; Presentation «What are BSC and KPI and why we need?» for medical staff; Workshops for the definition and description of the processes in departments, wards, structural units; Workshops for the development of Balanced Scorecard for the Center of Pediatrics; Trainings for the administrative and medical staff how to use Computer program for BSC 
and $\mathrm{KPI}$ for the Center of Pediatrics; Implementation of the Computer program for BSC and KPI for the Center of Pediatrics.

According to this purpose we proposed some complex of measures for different categories of personnel which can be included in «Strategic Development Program for the period 2020-2025" in the Center of Pediatrics named after the John Paul II in Sosnowiec. The Complex of measures for different categories of personnel in "Strategic Development Program for the period 2020-2025» includes different actions such as seminars, workshops, conduction of annual surveys for the different categories of medical staff.

As expected results of this «Strategic Development Program for the period 2020-2025" will be noted: development of new Internal codex of organizational culture in the Center of Pediatrics which maintain the responsible behavior of the personnel according to standards defined in internal codex of organizational culture; improvement system of motivation for personnel which decrease the possible reasons of professional burnout and improve the working conditions for staff; improvement of cooperation between professionals, doctors, nurses and other medical workers from different departments and wards which based on development of team work, better coordination of activities and information outflows; improvement of communication of medical staff with children of different age groups for the medical staff and promotion of different preventive programs for physical and mental health support.

\section{Discussions and Conclusions}

The healthcare sector is developing sector in Poland and an example of a social infrastructure industry where human resources management plays an important role. The Silesian Voivodship occupies significant positions in a number of segments related to medical services. This Voivodship has rather a large potential of medical specialists due to the existence of the Silesian Medical University, higher medical schools and a number of universities that train medical staff in such specialties as a nurse, medical lifeguard, nutritionist, social worker, etc. At the same time, despite the increase in the number of students studying in medical specialties and graduates of medical universities and medical schools, in many medical organizations in Poland and, in particular, the Silesian Voivodship, there is a personnel shortage, especially among doctors of certain specialties, nurses, and orderlies. One of the reasons is the high labor migration of medical personnel from Poland to other EU countries, where wages are several times higher.

In this regard, the problem of strategic human resources management in medical organizations in Poland is extremely urgent. The Center of Pediatrics, 
taken as an example for study and analysis of human resources, is one of the leading specialized centers in the Silesian Voivodship for the diagnosis, treatment and prevention of diseases in pediatric patients.

We analyzed the dynamics of the strategic positions of the Center of Pediatrics over the past five years and studied the positions of the Center of Pediatrics in comparison with other pediatric centers and clinics in Poland, as well as in comparison with the positions in the ranking of medical organizations in the Silesian Voivodship. It was noted that in recent years, the Center of Pediatrics has somewhat lowered its position in the ranking. It may result in assessment reduction of the organization's competitiveness and its attractiveness to promising medical specialists.

Nevertheless, almost all respondents indicated a low level of funding and the necessity to increase wages, though the importance of other methods, such as conducting next reforms of the health care system, fighting corruption, etc. has not been mentioned. There are also certain problems with communication, especially with patients, through new information technologies, application of using electronic resources, and public discussion of the quality of medical services by patients.

Taking into consideration, the identified features of the state of human resources at the Center of Pediatrics, we have developed recommendations for the implementation of the Balanced Scorecard method and other strategic human resource management methods. Among these recommendations, there are SWOT analysis, audit and planning of human resource development, development of the KPI (Key Performance Index) method for assessing the level qualifications, skills of medical personnel and increase the efficiency of its work. Due to these plans and complex of measures for the strategical development it will be possible to measure the efficiency of the different categories of medical staff, to create portfolio of professional achievements for the physicians and researchers, who work in the Center of Pediatrics. These proposals will increase impact of additional knowledge and skills of the human resources on evaluation of competitiveness of the Center of Pediatrics in Sosnowiec and to improve its positions in national ratings for leading hospitals in Poland.

\section{Acknowledgements}

The paper is the output of a scientific project IGA 3/2020-M «Improving Healthcare efficiency: new trends and challenges». (Funder: VSEMvS IGA VSEMvs, i.e. School of Economics and Management in Public Administration) 


\section{References}

1. Armstrong, M. (2006). Strategic human resource management: a guide to action (3rd ed.). Kogan Page.

2. Armstrong, M., \& Taylor, S. (2017). Armstrong's Handbook of Human Resource Management Practice (14th ed.). Kogan Page.

3. Boxall, P., \& Purcell, J. (2008). Strategy and Human Resource Management (2nd ed.). Palgrave MacMillan.

4. Centrum Monitorowania Jakosci w Ochronie Zdrowia. (2015). The best hospitals: Multi-specialized procedures [in Polish]. https://www.cmj.org.pl/ranking/wyniki_2015/index.php?typ=publiczne

5. Centrum Monitorowania Jakosci w Ochronie Zdrowia. (2016). The best hospitals: Multi-specialized procedures [in Polish]. https://www.cmj.org.pl/ranking/wyniki_2016/index.php?typ=publiczne

6. Centrum Monitorowania Jakosci w Ochronie Zdrowia. (2017). The best hospitals: Multi-specialized procedures [in Polish]. https://www.cmj.org.pl/ranking/wyniki_2017/index.php?typ=zwonk

7. Centrum Monitorowania Jakosci w Ochronie Zdrowia. (2018). The best hospitals: Multi-specialized procedures [in Polish]. https://www.cmj.org.pl/ranking/wyniki_2018/index.php?typ=zwonk

8. Detyna, B., \& Detyna J. (2011). Quality of medical services. Statistical evaluation. Methodological basics [in Polish]. Difin.

9. Dubrovina, N., Siwiec, A., Dubrovina, V., \& Tulai, O. (2019). Perspectives of the development of human resources management in the center of pediatrics. In M. Duczmal, M. Azhazha, S. Filip (Eds.), Improving the Life Quality: View of Scientists, Volume of Scientific Papers, (pp. 306-314). The Academy of Management and Administration in Opole.

10. Hass-Symotiuk, M. (Ed.). (2011). A system of measurement and evaluation of a hospital [in Polish]. Wolters Kluwer Polska Sp.z.o.o.

11. Kabene, S. M., Orchard, C., Howard, J. M., Soriano, M. A., \& Leduc, R. (2006). The importance of human resources management in health care: A global context. Human resources for health, 4(1), 20. https://doi.org/ 10.1186/ 1478-4491-4-20

12. Kiliková, M., \& Jakušová, V. (2016). Theory and practice of management in nursing [in Slovak]. Martin, Osveta. 
13. Korpalska, W. (Ed.). (2015). Polish hospitals [in Polish]. Wydawnictwo „Promocja».

14. Mathias, R., \& Jackson, J. (2006). Human Resource Management (11th ed.). South Western.

15. Miles, R. E., \& Snow, C. C. (1984). Designing strategic human resources systems. Organizational Dynamics, 13(1), 36-52. https://www.sciencedirect.com/ science/article/pii/0090261684900305?via\%3Dihub

16. Nica, E. (2013). The importance of human resources management to the health system. Journal of Economics, Management, and Financial Markets, 4(8), 166-171.

17. Nica, E. (2016). The effect of perceived organizational support on organizational commitment and employee performance. Journal of Self-Governance and Management Economics, 4(4), 34-40.

18. Nicolaescu, E. (2013). Business ethics, corporate governance, and social responsibility. Journal of Self-Governance and Management Economics, 1(1), 86-92.

19. Ondruš, P., \& Ondrušová, I. (2017). Management and financing in healthcare [in Slovak]. Turany.

20. Statistics Poland. (2018). Health and health care in 2017. Statistical Office in Krakow.

21. Stępniewski, J. (Ed.). (2009). Organization and management of hospitals selected issues [in Polish]. Wydawnictwo Uniwersytetu Jagiellońskiego.

22. Swayne, L. E., Duncan, J. W., \& Ginter, P. M. (2006). Strategic management of health care organizations (5th ed.). Blackwell Publishing Ltd.

23. Tucmeanu, A. I. (2014). The economics of health care system reform. Journal of Self-Governance and Management Economics, 2(2), 72-77.

24. Vulcanescu, R. T. (2014). Improvement of public health performance based on cost-effectiveness. Journal of Self-Governance and Management Economics, 2(2), 38-43.

25. Wright, P. M., Snell, S. A., \& Dyer, L. (2005). New models of strategic HRM in a global context. International Journal of Human Resource Management, 16(6), 875-881. https://doi.org/10.1080/09585190500120814 